\title{
Characterization of acidic endoglucanase Cel12A from Gloeophyllum trabeum and its synergistic effects on hydrogen peroxide-acetic acid (HPAC)-pretreated lignocellulose
}

\author{
Chi Hoon Oh ${ }^{1}$, Chan Song Park', Yoon Gyo Lee ${ }^{2}$, Younho Song ${ }^{2}$ and Hyeun-Jong Bae $e^{1,2^{*}}$
}

\begin{abstract}
Gloeophyllum trabeum is a potent filamentous fungus that rapidly decomposes lignocellulose. In the present study, we cloned the G. trabeum cel12a gene and expressed it in Pichia pastoris strain GS115. The purified recombinant GtCel12A exhibited high pH stability and very high specific enzymic activity against $\beta$-glucan $\left(6546 \mathrm{U} \mathrm{mg}^{-1}\right)$ and carboxymethyl cellulose $\left(1129 \mathrm{U} \mathrm{mg}^{-1}\right.$ ) compared to GtCel5B, endoglucanases from Trichoderma reesei, and other glycoside hydrolase family 12 (GH12) enzymes. GtCel12A exhibited high enzymic activity with regard to hydrogen peroxide-acetic acid (HPAC)-pretreated lignocellulose biomass, and produced cellobiose as a major product with a small quantity of glucose. In combination with commercial cellulase, this enzyme also showed synergistic effects of 14.5, 16.1, 29.0, and 13.4\% on filter paper, HPAC-pretreated pine, corn stover, and rice straw, respectively. The acidic endoglucanase GtCel12A from G. trabeum is a promising tool that can be used in combination with cellulase against HPAC-pretreated lignocellulose.
\end{abstract}

Keywords: HPAC-pretreatment, Endoglucanase, Synergistic effects, Pichia pastoris

\section{Introduction}

Approximately 200 billion tons of lignocellulose are produced every year. These renewable polymers can be used to produce biofuel or biochemicals without competing with the first-generation feedstocks [1]. Enzymatic hydrolysis, which converts lignocellulose into its monomeric sugars, requires a hydrolytic enzyme complex [2]. A synergistic cooperation of cellulases, comprising exo-1,4- $\beta$-glucanases (EC 3.2.1.91 and EC 3.2.1.176) and endoglucanase (EC3.2.1.4), is important for the complete hydrolysis of lignocellulose. Endoglucanases, which hydrolyze the internal glucosidic bonds, provide exo-1,4- $\beta$-glucanases with new reducing and nonreducing ends. Enzymes have been widely used in the pulp and paper, textile, bioethanol, wine and brewery, food processing, animal feed, agricultural, biomolecular chemical

\footnotetext{
*Correspondence: baehj@chonnam.ac.kr

${ }^{1}$ Department of Bioenergy Science and Technology, Chonnam National

University, Gwangju 61186, Republic of Korea

Full list of author information is available at the end of the article
}

products, and pharmaceutical industries [1, 3, 4]. Cellulases comprise approximately $20 \%$ of the global enzyme market [5]. Currently, the main source for commercial and industrial cellulases is Trichoderma reesei, a wellstudied and -established fungus used to produce cellulase at a scale of more than $100 \mathrm{~g} \mathrm{~L}^{-1}[6,7]$. However, the production cost of cellulase accounts for approximately $40 \%$ of the total cost of bioethanol production from lignocellulose biomass [1]. Therefore, the development of effective enzymes or an enzyme cocktail is essential to enhance enzyme efficiency.

Among bacteria and fungi, brown rot basidiomycetes have been studied extensively for their ability to rapidly decompose lignocellulosic biomass, despite lacking the processive cellobiohydrolases [8]. Cellulase-encoding gene sequences have been reported in Gloeophyllum trabeum [9]. This fungus is also one of the most potent and a well-studied microorganism that degrades lignocelluloses [8, 10-12]. G. trabeum is able to depolymerize lignocellulose biomass using a unique system combining 
nonenzymatic lignocellulose degradation, which is Fenton-type reactions mediated by reducing $\mathrm{Fe}^{3+}$ and $\mathrm{O}_{2}$ with two hydroquinones $[11,12]$, with enzymatic lignocellulose degradation $[8,10]$.

Endoglucanases are grouped into 14 glycoside hydrolase (GH) families within the Carbohydrate-Active enZYmes database (CAZy; http://www.cazy.org/Glyco side-Hydrolases.html). Among these, the GH 12 family has a $\beta$-jelly roll structure with relatively low molecular mass and several catalytic activities, including endoglucanase (EC 3.2.1.4), xyloglucan hydrolase (EC 3.2.1.151), $\beta-1,3-1$,4-glucanase (EC 3.2.1.73), and xyloglucan endotransglucosylase (EC 2.4.1.207). Most of GH12 have two conserved cystines region that form a disulfide bridge, which offers enzyme structures local stabilization. This family of endoglucanases plays a critical role during the hydrolysis of $\beta-1,3-1,4$ and $\beta-1,4$-glucan with high activities [13].

A variety of recombinant endoglucanases and xyloglucan-specific endoglucanases in the GH12 family have been cloned and studied using various hetero-expression hosts [14-18]. A G. trabeum endoglucanase expressed in a host, Aspergillus niger, has been characterized in terms of molecular weight, thermal stability, and optimal activity conditions [16, 19]. Tambor et al. [19] have also reported a synergistic relationship between endoglucanases and T. reesei Cel7A with regard to the digestion of filter paper. However, there is insufficient information about enzyme activity with regard to the digestion of lignocellulose substrates and synergistic relationship with cellulase. Pichia pastoris provides a well-studied eukaryotic heterologous expression system with numerous advantages, including protein folding, protein processing, posttranslational modification, and high expression [20-22]. In the present study, we describe the expression, purification, and biochemical characterization of acidic GtCel12A from P. pastoris. We also studied the synergistic effects of GtCel12A with commercial cellulase on hydrogen peroxide-acetic acid (HPAC)-pretreated lignocellulose from pine, corn stover, and rice straw.

\section{Materials and methods}

\section{Substrate materials}

Pine wood and chips were obtained from the arboretum of Chonnam National University, South Korea. Rice straw and corn stover were purchased online (http://www. gmarket.co.kr/). Lignocellulose biomass were pretreated with HPAC, according to a procedure reported previously [23]. Following pretreatment, residues after the pretreatment were washed with hot water until attaining neutral $\mathrm{pH}$ and then freeze-dried.

\section{Microbial strains, media, and cultivation conditions}

The filamentous fungus G. trabeum strain ATCC11539 was used as a gene source for cel12a. The fungus was grown on potato dextrose agar (PDA) medium at $30{ }^{\circ} \mathrm{C}$ for 5 days and then transferred into $100 \mathrm{~mL}$ Avicel medium ( $10 \mathrm{~g} \mathrm{~L}^{-1}$ Avicel, $5 \mathrm{~g} \mathrm{~L}^{-1}\left(\mathrm{NH}_{4}\right)_{2} \mathrm{SO}_{4}, 2 \mathrm{~g} \mathrm{~L}^{-1}$ $\mathrm{KH}_{2} \mathrm{PO}_{4}, 0.3 \mathrm{~g} \mathrm{~L}^{-1} \mathrm{CaCl}_{2}, 0.3 \mathrm{~g} \mathrm{~L}^{-1} \mathrm{MgSO}_{4} \cdot 7 \mathrm{H}_{2} \mathrm{O}$, $1 \mathrm{~g} \mathrm{~L}^{-1}$ protease peptone, $0.2 \%(v / v)$ Tween 80 , and $0.2 \%$ $(v / v)$ trace elements solution) trace elements solution; $5 \mathrm{~g} \mathrm{~L}^{-1} \mathrm{FeSO}_{4} \cdot 7 \mathrm{H}_{2} \mathrm{O}, 1.6 \mathrm{~g} \mathrm{~L}^{-1} \mathrm{MnSO}_{4} \cdot \mathrm{H}_{2} \mathrm{O}, 1.4 \mathrm{~g} \mathrm{~L}^{-1}$ $\mathrm{ZnSO}_{4} \cdot 7 \mathrm{H}_{2} \mathrm{O}$, and $2 \mathrm{~g} \mathrm{~L}^{-1} \mathrm{CoCl}_{2}$ ) contained in a 500 $\mathrm{mL}$ baffle flask at $30^{\circ} \mathrm{C}$ for 5 days in a $180 \mathrm{rpm}$ shaking incubator. The TOP10 E. coli strain was transformed and grown on Luria-Bertani (LB) medium at $37{ }^{\circ} \mathrm{C}$ for 18 h. Yeast strain Pichia pastoris GS115 was grown step-by-step on YPD media $\left(10 \mathrm{~g} \mathrm{~L}^{-1}\right.$ yeast extract, $20 \mathrm{~g} \mathrm{~L}^{-1}$ protease peptone, and $10 \mathrm{~g} \mathrm{~L}^{-1}$ dextrose), YPG (10 $\mathrm{g} \mathrm{L}^{-1}$ yeast extract, $20 \mathrm{~g} \mathrm{~L}^{-1}$ protease peptone, and $1 \%(v / v)$ glycerol $)$ at $30{ }^{\circ} \mathrm{C}$ for $24 \mathrm{~h}$, respectively. After cultivation on the YPG medium, the yeast cell was harvested and transferred onto YP medium $\left(10 \mathrm{~g} \mathrm{~L}^{-1}\right.$ yeast extract, $20 \mathrm{~g} \mathrm{~L}^{-1}$ protease peptone) with $0.8 \%(v / v)$ methyl alcohol added every $24 \mathrm{~h}$, for heterologous protein expression at $30{ }^{\circ} \mathrm{C}$ for 4 days.

\section{Gtcel12a gene cloning}

The G. trabeum was harvested for total RNA extraction by centrifuging at 13,000 rpm (Avanti J-E, Beckman, Fullerton, CA, USA) for 30 min after cultivation in PDB medium with $1 \%(w / v)$ Avicel. To extract total RNA from G. trabeum, the TRIzol reagent kit (Invitrogen, Carlsbad, CA, USA) was used. The SMART cDNA library construction kit (TaKaRa, Mountain View, CA, USA) was used for cDNA synthesis with isolated RNA. Gene sequences of GtCel12a were amplified by Polymerase chain reaction (PCR) using designed primers (GtCel12A-F 5'-GAA TTC GCG ACC GTG CTC ACT GGT CAA TAC-3' and GtCel12A-R 5'-CTG CAG CCC GCT CAA GCT GAC GCT GAA-3') without the signal peptide. PCR was performed in a volume of $20 \mu \mathrm{L}$, containing $3 \mu \mathrm{L}$ first strand cDNA, $2 \mu \mathrm{L} 10 \times$ Ex Taq buffer, $2 \mu \mathrm{L}$ dNTP, $1 \mu \mathrm{L}$ each of forward and reverse primers, and $0.1 \mu \mathrm{L}$ Ex Taq DNA polymerase $\left(5 \mathrm{U}_{\mu} \mathrm{L}^{-1}\right)$ under the following conditions: 1 cycle of denaturation at $95{ }^{\circ} \mathrm{C}$ for $30 \mathrm{~s}$, and 35 cycles of annealing at $60{ }^{\circ} \mathrm{C}$ for $30 \mathrm{~s}$, extension at $72{ }^{\circ} \mathrm{C}$ for $60 \mathrm{~s}$. The resulting PCR products were cloned into the pGEM-T Easy vector (Promega, Madison, WI, USA) with EcoRI and PstI restriction enzymes and then sequenced and transformed into TOP10F E. coli strain. The transformants were selected on LB medium with ampicillin. 
Heterologous enzyme expression, purification, western blot, and sodium dodecyl sulfate polyacrylamide gel electrophoresis (SDS-PAGE) analysis

The Gtcel12a gene was subcloned into the pPICZ $\alpha \mathrm{A}$ vector (Invitrogen) with restriction enzymes, EcoRI and PstI, and then it was transformed into host strain, $P$. pastoris GS115, for heterologous expression. The transformants were selected on YPD medium with the antibiotics zeocin. Cells were harvested by centrifuging at $13,000 \mathrm{rpm}$ for $30 \mathrm{~min}$. The supernatant was then filtered through a GF/C glass microfiber filter $(1.2 \mu \mathrm{m})$ to remove any remaining yeast cells, and then purified using a column, containing $1 \mathrm{~mL} \mathrm{Ni-NTA}$ matrix (Qiagen, Hilden, Germany). GtCel12A expression was confirmed through a western blot assay with mouse anti-His-tagged antibody (Abfrontier, Seoul, South Korea). The purified enzymes were dialyzed in $20 \mathrm{mM}$ tris-hydrochloride buffer ( $\mathrm{pH}$ 8.0). The protein concentration was determined by a Bradford assay at $595 \mathrm{~nm}$ with bovine serum albumin (BSA) as a standard. SDS-PAGE analysis was conducted to determine the molecular mass of a heterologous expressed enzyme using a $12 \%(w / v)$ polyacrylamide gel stained with Coomassie brilliant blue R-250.

\section{Biochemical characterization}

The optimal $\mathrm{pH}$ was determined by measuring the relative activity of enzymes in $50 \mathrm{mM}$ buffers ranging from $\mathrm{pH} 2.0$ to 9.0, glycine-hydrochloric acid ( $\mathrm{pH} 2.0-3.0)$, sodium acetate $(\mathrm{pH} 4.0-5.0)$, sodium phosphate $(\mathrm{pH}$ 6.0-7.0), and tris-hydrochloride (pH 8.0-9.0) in 1\% $(w / v)$ solution of carboxymethyl cellulose $(\mathrm{CMC})$ at $50{ }^{\circ} \mathrm{C}$, following a dinitrosalicylic acid (DNS) assay by using a spectrophotometer (Multiskan EX, Thermo Fisher Scientific, Vantaa, Finland) at $550 \mathrm{~nm}$. The optimal temperature was determined by monitoring the relative activity at temperature ranging from 20 to $70{ }^{\circ} \mathrm{C}$ in $50 \mathrm{mM}$ glycinehydrochloric acid buffer ( $\mathrm{pH} 2.5)$ with CMC. $\mathrm{pH}$ stability was assessed according to the residual enzyme activity after preincubation in various buffers (ranging from $\mathrm{pH}$ 2.0 to 9.0 ) at $4{ }^{\circ} \mathrm{C}$ for $18 \mathrm{~h}$. Thermal stability was likewise determined by monitoring residual enzyme activity after preincubation at $30-60^{\circ} \mathrm{C}$ for $0-120 \mathrm{~min}$.

\section{Enzyme assays}

Nine materials were used as enzyme assay substrates: Avicel PH-101 (microcrystalline cellulose, ca. $50 \mu \mathrm{m}$ ), xyloglucan from tamarind, $\beta$-glucan from barley (Megazyme), filter paper (Whatman number 1), locust bean gum from Ceratonia siliqua seeds, xylan from beech wood, carrageenan, $\mathrm{CMC}$, and soluble starch (all purchased from Sigma). These substrates were prepared as $1 \%$ stock solutions. Each enzymatic assay was performed in triplicate in a final volume of $100 \mu \mathrm{L}$, containing $50 \mu \mathrm{L}$ substrate stocks, $50 \mathrm{mM}$ glycine-hydrochloric acid buffer ( $\mathrm{pH} 2.5$ ), and diluted enzyme. The kinetic parameters, $K_{m}$ and $V_{\max }$, were evaluated with $0.25-2.0 \% \mathrm{CMC}$ as a substrate for 5 min under optimal conditions $\left(\mathrm{pH} 2.5,50{ }^{\circ} \mathrm{C}\right)$ and estimated using Lineweaver-Burk plot. To determine the effects of chemical and ions, $50 \mathrm{mM}$ of EDTA, $\mathrm{NaCl}$, $\mathrm{LiCl}, \mathrm{KCl}, \mathrm{CoCl}_{2}, \mathrm{ZnCl}_{2}, \mathrm{CaCl}_{2}, \mathrm{MnCl}_{2}, \mathrm{HgCl}_{2} \mathrm{AlCl}_{3}$, and $\mathrm{FeCl}_{3}$ were tested. Reducing sugars were measured using dinitrosalicylic acid reagent with a glucose standard curve [24]. One unit (U) was defined as the amount of enzyme required to produce $1 \mu \mathrm{mol}$ of reducing sugars per min. Products degraded from oligosaccharides were prepared by purified enzymes in a $100 \mu \mathrm{L}$ final volume with $50 \mathrm{mM}$ glycine-hydrochloric acid buffer $(\mathrm{pH}$ $2.5)$, diluted enzyme, and each substrate, containing $1 \%$ $(w / v)$ cellobiose, cellotriose, cellotetraose, or cellopentaose. These mixtures were incubated at $50{ }^{\circ} \mathrm{C}$ for 1 to $20 \mathrm{~min}$, followed by loading $1 \mu \mathrm{L}$ of released products on thin-layer chromatography (TLC) silica gel 60 plates and separated with $n-\mathrm{BuOH} / \mathrm{CH}_{3} \mathrm{O}_{2} \mathrm{H} / \mathrm{H}_{2} \mathrm{O}(2: 1: 1 v / v)$. Sugars were detected using a $5 \%(v / v) \mathrm{H}_{2} \mathrm{SO}_{4}$ in methanol staining solution [25].

\section{Enzymatic hydrolysis and synergistic effect with commercial cellulase}

Hydrolysis was performed under their optimal conditions of GtCel12A and GtCel5B [24]. Synergistic effects were examined using a $3 \%(w / v)$ solution of HPAC-pretreated lignocellulose and filter paper, $50 \mathrm{mM}$ citrate buffer $(\mathrm{pH}$ 4.8), $10 \mathrm{FPU} \mathrm{g}^{-1}$ commercial cellulase (Celluclast $1.5 \mathrm{~L}$, Novozymes, Denmark), and $30 \mathrm{U} \mathrm{g}^{-1}$ in pine, $50 \mathrm{U} \mathrm{g}^{-1}$ GtCel12A in filter paper, corn stover, and rice straw at $48^{\circ} \mathrm{C}$ for $24 \mathrm{~h}$. The reducing sugars were determined by a DNS assay and high-performance liquid chromatography (HPLC) (Waters, Milford, MA, USA) with a Rezex RPM column $(300 \times 4.6 \mathrm{~mm}$; Phenomenes, Torrance, CA, USA). The analysis conditions were 85 and $40{ }^{\circ} \mathrm{C}$ in the column and refractive index detector, respectively, with deionized water at a flow rate of $0.6 \mathrm{~mL} \mathrm{~min}{ }^{-1}$.

\section{Results and discussion}

\section{Gene cloning and sequence analysis}

We obtained the cel12a gene (National Center for Biotechnology Information (NCBI) accession number HQ163778) from G. trabeum ATCC 11539 and confirmed it by sequence analysis. This gene includes 741 nucleotides, encoding 246 amino acids with a calculated molecular weight of $26.17 \mathrm{kDa}$ and a theoretical isoelectric point of 4.10. The SignalP 4.1 server (http://www. cbs.dtu.dk/server/SignalP) predicted that GtCel12A has signal peptides from amino acids 1 to 21 . The amino acid sequence of the GtCel12A was aligned by BLAST 
(http://www.uniprot.org/blast/) with 12 other fungal family endoglucanases and visualized using the Vector NTI software. Multiple alignment analysis showed that the GtCel12A had high identities with other brown-rot fugal GH12 endoglucanases, Neolentinus lepideus (87.3\% identity), Laetiporus sulphureus (65.2\% identity), Postia placenta (67.4\% identity), and Daedalea quercina (63.8\% identity) (Additional file 1: Fig. S1). Therefore, these results indicate that $G t$ Cel12A belongs to the typical glycolyl hydrolase family 12 , which is a specific endoglucanase of brown-rot fungi.

\section{Expression and purification of recombinant GtCel12A in the P. pastoris}

GtCel12A has been reported in its native form, and in heterologous protein expression from Aspergillus niger $[10,16,19]$. The Gtcel12a gene was expressed in the host P. pastoris GS115 using a pPICZ $\alpha$ A vector without signal peptides, owing to an unfavorable $\mathrm{N}$-terminal secretion signal in the yeast [25]. The expressed enzyme was purified using a Ni-NTA agarose affinity column and dialyzed with $20 \mathrm{mM}$ tris-hydrochloride buffer ( $\mathrm{pH}$ 8.0). The expressed GtCel12A protein was confirmed by western blot assay (Additional file 1: Fig. S2a). SDS-PAGE showed that the molecular weight of the purified protein from $P$. pastoris was approximately $31 \mathrm{kDa}$, which was larger than the calculated molecular mass (Additional file 1: Fig. S2b). Recombinant GtCel12A expressed from $A$. niger strain CBS513.88 and py11 had different protein molecular masses, of 29 and $26.1 \mathrm{kDa}$, respectively [16, 19]. Recombinant EGIIIs (Cel12A) of Trichoderma reesei was expressed in heterologous hosts E. coli, Saccharomyces cerevisiae, and Schizosaccharomyces pombe, which likewise showed different molecular masses $(25,28$, and $29 \mathrm{kDa}$, respectively) due to $\mathrm{N}$-glycosylation by the different hosts. The molecular mass was decreased to $25 \mathrm{kDa}$ by endoglycosidase $\mathrm{H}$ and $\alpha$-mannosidase treatment [26]. These increases in molecular weight may be at least partly related to glycosylation by a heterologous host in the recombinant $G t C e l 12 \mathrm{~A}$ protein.

\section{Characterization of the GtCel12A}

To determine the biochemical characterization of $G t$ Cel12A, the effect of $\mathrm{pH}$ and temperatures was conducted on the CMC substrate. The GtCel12A expressed from $P$. pastoris exhibited enzyme activity over a range of extremely acidic conditions ( $\mathrm{pH} 2.0-4.0)$ with an optimal pH 2.5, showed residual relative enzyme activity exceeding $80 \%$ across the range of $\mathrm{pH}$ conditions tested, and was highly stable at base conditions of $\mathrm{pH}$ 8.0-9.0 (Fig. 1a). In contrast, the GtCel12A expressed by $A$. niger has an optimal $\mathrm{pH}$ of 4.5 , indicating $\mathrm{N}$-glycosylation of the protein molecule $[16,19]$. Similarly,
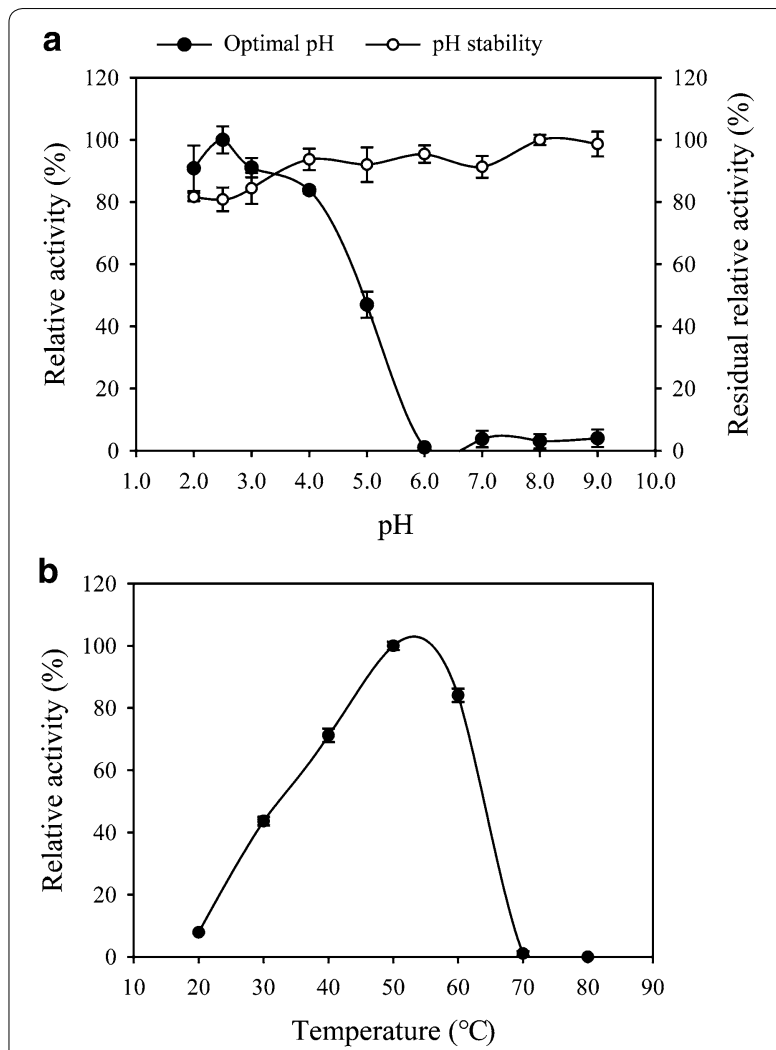

c

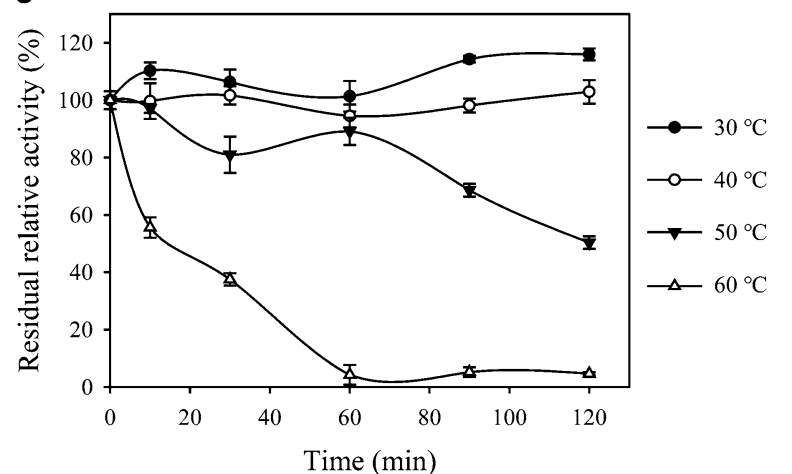

Fig. 1 Characterizations of optimal pH, temperature, and stability of recombinant GtCel12A. a The optimal pH and pH stability were measured at $50^{\circ} \mathrm{C}$ with $50 \mathrm{mM}$ buffers at a $\mathrm{pH}$ range of $\mathrm{pH}$ 2.0-9.0 on CMC; pH stability was determined by monitoring residual activity after preincubation without substrate for $18 \mathrm{~h}$ at $4^{\circ} \mathrm{C}$. b Optimal temperature was determined at various temperatures $\left(20-80^{\circ} \mathrm{C}\right)$ in $50 \mathrm{mM}$ glycin- $\mathrm{HCl}(\mathrm{pH} 2.5)$. c Thermal stability was determined at $50^{\circ} \mathrm{C}$ in $50 \mathrm{mM}$ glycin- $\mathrm{HCl}(\mathrm{pH} 2.5)$ by the preincubated enzyme in $30-60^{\circ} \mathrm{C}$ for various time $(0,10,30,60,90$, and $120 \mathrm{~min})$. All of error bars indicate $\pm S D$

other GH12 endoglucanases from fungi have been reported to have an optimal ( $\mathrm{pH}$ values $\mathrm{pH}$ 5.0-6.0) $[17,27]$. Optimal enzyme activity was found to occur at $50{ }^{\circ} \mathrm{C}$ within a tested range of $20-80{ }^{\circ} \mathrm{C}$ (Fig. 1b).

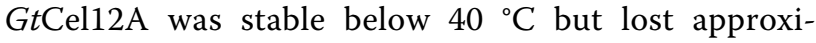
mately half of its activity at $50{ }^{\circ} \mathrm{C}$ after $120 \mathrm{~min}$ (Fig. 1c). 


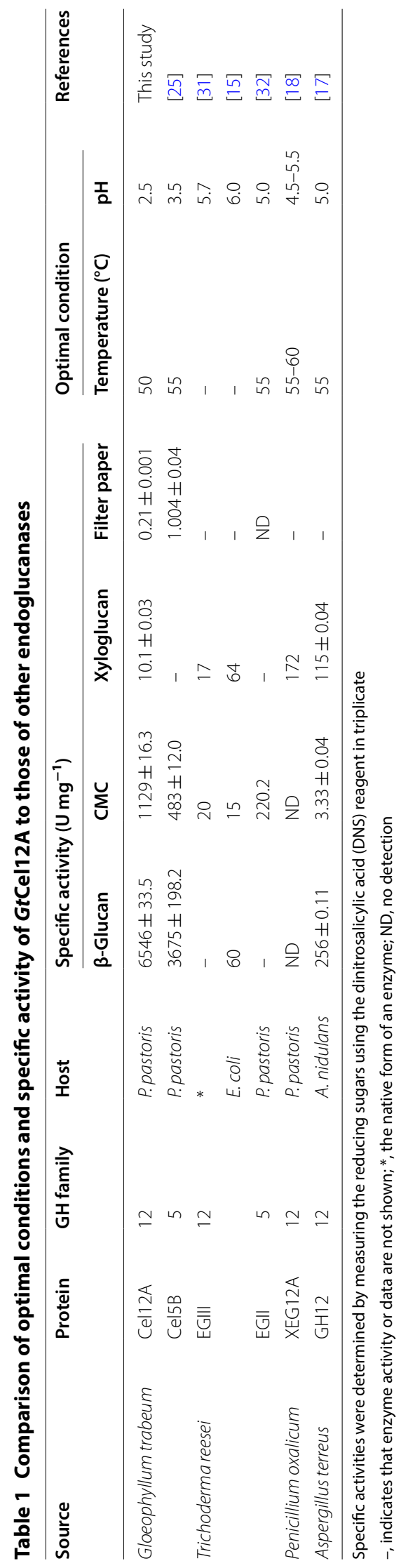


This result consistent with the observed stability of GtCel12A expressed from A. niger [19].

The specific activity of the purified recombinant enzyme was assayed using various substrates (Additional file 1: Table S1). The enzyme exhibited significantly higher specific activity toward $\beta$-glucan $\left(6546 \mathrm{U} \mathrm{mg}^{-1}\right)$ and CMC (1129 $\mathrm{U} \mathrm{mg}^{-1}$ ), which represent the $\beta$-1,3$1,4-$ and $\beta$-1,4-linkages, respectively, than toward xyloglucan $\left(10.1 \mathrm{U} \mathrm{mg}^{-1}\right)$ and filter paper $\left(0.21 \mathrm{U} \mathrm{mg}^{-1}\right)$. It did not degrade Avicel, xylan, soluble starch, locust bean gum, or carrageenan. The results of substrate preference were similar to that of $G t$ Cel12A expressed by A. niger [16]. The GtCel12A had detectable enzyme activities against both $\beta$-glucan and xyloglucan. Thus, GtCel12A can be classified into SF 12-1 of the GH12 family [28]. The kinetic parameters of GtCel12A were as follows: $V_{\max }=3452 \mu \mathrm{mol} \mathrm{min}{ }^{-1} \mathrm{mg}^{-1}, K_{m}=13.83 \mathrm{mg} \mathrm{mL}{ }^{-1}$, and $k_{\text {cat }}=1726 \mathrm{~s}^{-1}$ as determined by a Lineweaver-Burk plot. Table 1 shows the characteristics of GtCel12A in comparison with other endoglucanases from various fungal genera including Trichoderma, Aspergillus, and Penicillium. Such fungi have been widely studied because they produce large quantities of cellulases and accepted commercial enzymes [29, 30]. The endoglucanases TrEGIII, TrEGII, PoXEG12A, and AtGH12 had low or zero enzyme activities with respect to $\beta$-glucan and $C M C$, while GtCel5B in previous study showed high specific activities. However, GtCel12A exhibited notable specific activities on both substrates compared to them. $[15,17,18,25,31,32]$.

The influences of metal ions and EDTA were tested. The relative activity of GtCel12A was $126.9 \%$ when EDTA was added, and relative activities in the presence of these metal ions $\left(\mathrm{Ca}^{2+}, \mathrm{Co}^{2+}, \mathrm{Cu}^{2+}, \mathrm{Mn}^{2+}, \mathrm{Zn}^{2+}, \mathrm{K}^{+}, \mathrm{Li}^{+}\right.$, or $\mathrm{Na}^{+}$) were $90-100 \%$ of the relative activities observed in the absence of these cofactors. However, relative activity was entirely lost following exposure to $\mathrm{Al}^{3+}, \mathrm{Fe}^{3+}$, and $\mathrm{Hg}^{2+}$. GtCel12A did not employ metal ions as a cofactor. Naika and Tiku [33] have shown that enzyme activity of GH12 endoglucanase was enhanced in the presence of EDTA, which can affect molecule to form an intermediate state that is well disposed for protein-substrate interaction.

The hydrolysis pattern of oligosaccharides, including cellobiose, cellotriose, cellotetraose, and cellopentaose, was assessed by TLC analysis (Fig. 2). GtCel12A

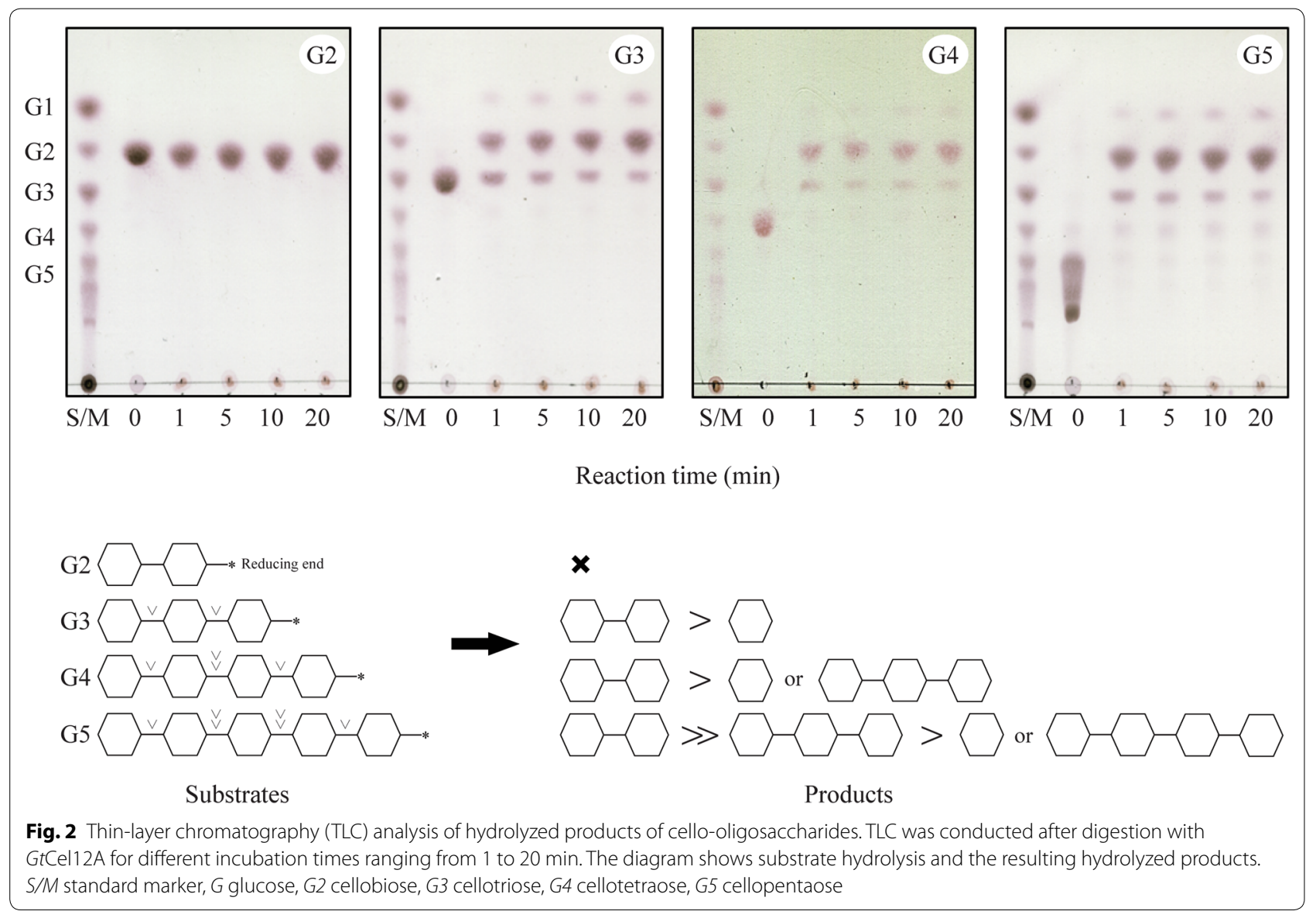


did not hydrolyze cellobiose into glucose; however, it did exhibit hydrolytic activity toward cellotriose, converting it into glucose and cellobiose. Cellotetraose was mainly degraded into cellobiose and minimally into glucose and cellotriose. Cellopentaose was likewise hydrolyzed by attacking its internal bonds, releasing cellobiose and cellotriose. In a previous study, $\operatorname{TrCel} 12 \mathrm{~A}$ did not degrade cellotriose into cellobiose and glucose, unlike GtCel12A [34]. However, the GtCel5B exhibited similar cello-oligomers hydrolysis patterns to those of GtCel12A, but with weaker hydrolysis activity for cellotriose [25]. For these reasons, recombinant acidic GtCel12A could be a candidate for use in numerous commercial industrial applications, as a superior enzyme with high catalytic efficiency and stability across a wide range of $\mathrm{pH}$ conditions.

\section{Enzymatic hydrolysis and synergistic effects of GtCel12A on the HPAC-pretreated lignocellulose}

Enzymatic hydrolysis of lignocellulose is impaired by several factors such as lignin, cellulose crystallinity, enzyme accessibility, and degree of polymerization. Lignin is the most important limiting factor for enzymatic hydrolysis because it limits the accessibility of cellulases to their substrates and directly inhibits cellulases [35, 36]. As a result, the enzymatic hydrolysis efficiency of lignocellulose is reduced by lignin. Therefore, an effective pretreatment method for lignocellulose is crucial to ensure a high conversion rate during enzymatic hydrolysis. A pretreatment method for lignocellulose biomass has been reported to effectively eliminate (97.2\%) of lignin from biomass. [23]. In the present study, we used the HPACpretreated lignocellulose as a substrate to assess enzyme activity and synergistic effects. Purified GtCel12A exhibited enzyme activities on HPAC-pretreated pine, rice straw, and corn stover and its characteristics were compared to those of GtCel5B endoglucanases because the GtCel5B showed more higher enzyme activities than other family 12 of glycoside hydrolase (GH12s) against $\beta$-glucan and CMC [25] (Fig. 3a). The pine substrate released 0.219 and $0.185 \mathrm{mg} \mathrm{mL}^{-1}$ reducing sugars via $G t$ Cel5B and GtCel12A, respectively. As a result, similar reducing sugar yield were achieved by both endoglucanases with respect to the pine substrates. However, $G t$ Cel12A achieved reducing sugar yields of 0.270 and $0.292 \mathrm{mg} \mathrm{mL}^{-1}$ from rice straw and corn stover, respectively, which were higher than the $0.144 \mathrm{mg} \mathrm{mL}^{-1}$ of reducing sugars that $G t$ Cel5B produced from each substrate. HPLC showed that GtCel12A produced cellobiose as a major product, and glucose as a minor product, from HPAC-pretreated lignocellulose (Fig. 3b). This result may correspond with the hydrolysis patterns of cello-oligomers determined by TLC analysis. Cellulose

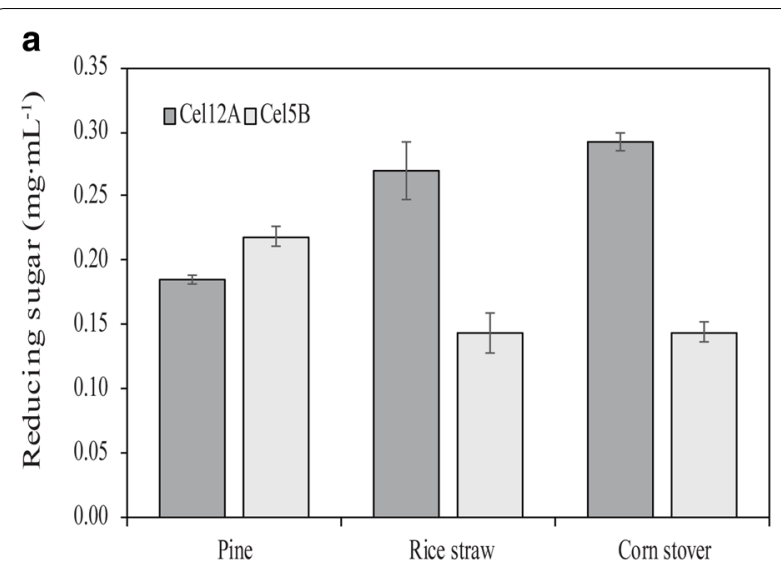

b

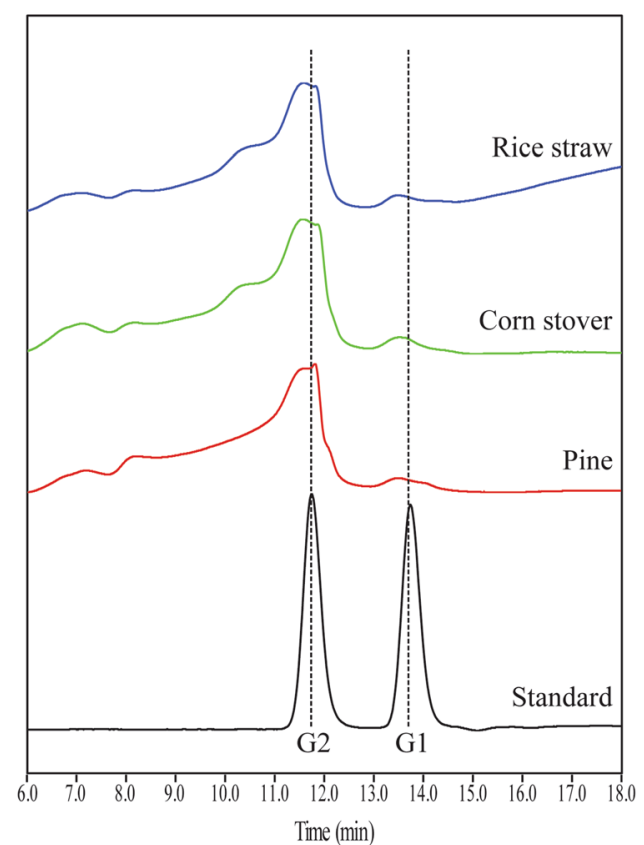

Fig. 3 Comparison of enzymatic hydrolysis on the HPAC-pretreated pine, corn stover, and rice straw. a Enzyme activities of GtCel12A and GtCel5B was compared under their optimal conditions for $24 \mathrm{~h}$ on HPAC-pretreated lignocellulose. Error bars indicate \pm SD. b Soluble sugars were analyzed by HPLC following enzymatic hydrolysis with purified GtCel12A. G1 glucose, G2 cellobiose

comprises a combination of crystalline and amorphous forms that can be easier to degrade than the crystalline regions [37]. The relative ratio of crystalline and amorphous cellulose regions varies according to the biomass source, which results in different degrees of degradability by enzymes. Certain grass-based biomasses contain significant quantities of $\beta$-glucan component in their cell walls. These conditions enabled GtCel12A to exhibit a high specific activity on $\beta$-glucan and CMC (Table 1 ). Miotto et al. [16] also reported that GtCel12A expressed 


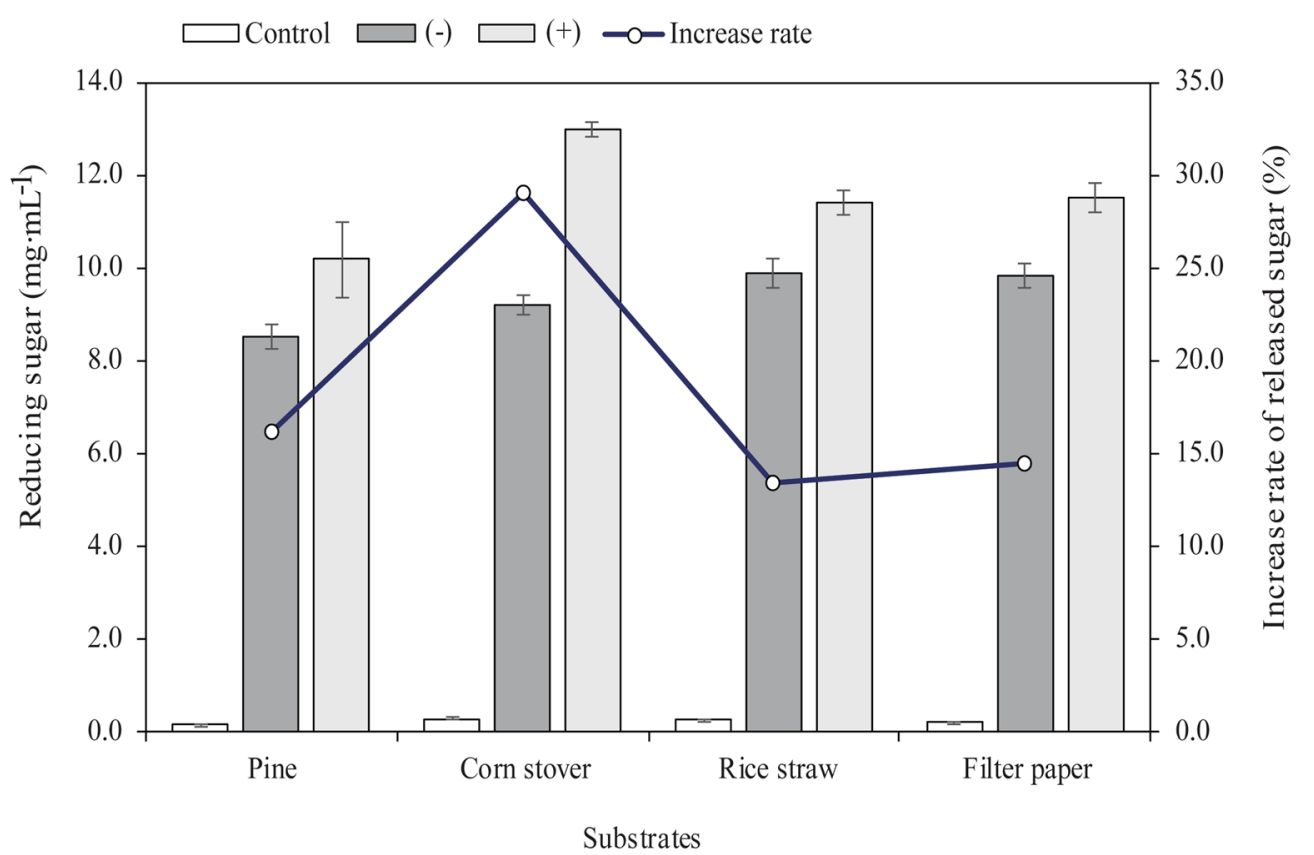

Fig. 4 Synergistic effects of GtCel12A with commercial cellulase on filter paper and HPAC-pretreated lignocellulose. Purified GtCel12A with 10 FPU g ${ }^{-1}$ cellulase was used on the $3 \%(\mathrm{w} / \mathrm{v})$ of the HPAC-pretreated substrates in $50 \mathrm{mM}$ citrate buffer $(\mathrm{pH} 4.8)$ at $48{ }^{\circ} \mathrm{C}$ for $24 \mathrm{~h}$. Control: GtCel12A alone, (-): cellulase alone, (+): cellulase with GtCel12A, increase rate: increase in the amount of released sugar (\%). Error bars indicate \pm SD

by $A$. niger had high enzyme activity with respect to $\beta$-glucan, and exhibited hydrolytic effects with respect to oat spelt. These results suggest that GtCel12A hydrolyzed grass-based biomass more efficiently than pine wood compared to GtCel5B. Furthermore, GtCel12A exhibited a higher specific activity on $\mathrm{CMC}$, which is amorphous cellulose, compared to GtCel5B. However, GtCel5B had higher specific activity on filter paper (Table 1). These results suggest that GtCel12A hydrolyzes amorphous cellulose more efficiently than GtCel5B, perhaps due to the cellulose crystallinity of the cellulose in HPAC-pretreated lignocellulose.

The synergistic cooperation of different types of cellulases is important for a high lignocellulose conversion rate. Endoglucanase, which acts on the internal glycosidic bonds in cellulose, creates new reducing and nonreducing ends for the exo-1,4- $\beta$-glucanases. When acting alone, $G t$ Cel12A achieved a reducing sugar yield of only $0.185 \mathrm{mg} \mathrm{mL}^{-1}$ from HPAC-pretreated pine. However, we detected a synergistic effect when we compared the amount of reducing sugars released from HPAC-pretreated pine lignocellulose by commercial cellulase alone with that released by commercial cellulase together with purified GtCel12A with enzymic activity of 10 filter paper units per gram $\left(\mathrm{FPU} \mathrm{g}^{-1}\right)$. An external supplement of purified GtCel12A increased reducing sugar production by 16.1, 29.0, 13.4, and
$14.5 \%$ on the HPAC-pretreated pine, corn stover, rice straw, and filter paper, respectively, compared to commercial cellulase alone (Fig. 4). In a previous study, synergistic effects of endoglucanases were reported to enhance hydrolysis efficiency: the GH12 family endoglucanase from $A$. terreus increased hydrolysis efficiency by $38.7 \%$ compared to crude cellulase alone on delignified rice straw [38]. Endoglucanase from Armillaria gemina KJS114 additionally showed enhanced reducing sugar production when combined with commercial cellulase mixtures on the pretreated poplar [39]. Increased enzymatic hydrolysis may be related to a synergistic action between the purified endoglucanase and commercial cellulase, and could also be enhanced by added endoglucanase, which causes an increase in the total amount of enzyme in the mixture [38]. Therefore, acidic GtCel12A could be a superior candidate for enzymatic hydrolysis of HPAC-pretreated lignocellulose.

\section{Conclusion}

The recombinant G. trabeum acidic endoglucanase Cel12A expressed by $P$. pastoris GS115 had an approximate molecular weight of $31 \mathrm{kDa}$, which differs from that of the enzyme expressed by $A$. niger. The purified GtCel12A expressed by P. pastoris had a more acidic 
optimal $\mathrm{pH}$ than that expressed by $A$. niger and exhibited superior $\mathrm{pH}$ stability across a range of $\mathrm{pH}$ values (2.0-9.0). Furthermore, GtCel12A exhibited a notable specific activity with regard to $C M C$ and $\beta$-glucan compared to GtCel5B, $\operatorname{TrCel} 12 \mathrm{~A}$, and other GH12 endoglucanases. GtCel12A exhibited better enzymatic hydrolysis on HPAC-pretreated rice straw and corn stover than GtCel5B. Moreover, it showed synergistic effects of 16.1, 29.0, 13.4, and 14.5\% on HPACpretreated pine, corn stover, rice straw, and filter paper, respectively, when $G t$ Cel12A was added as a supplement to cellulase. The GtCel12A with superior $\mathrm{pH}$ stability and enzyme activity could be a potential candidate as an additive enzyme for biotechnological application.

\section{Additional file}

Additional file 1: Figure S1. Multiple alignment of Gloeophyllum trabeum Cel12A amino acid sequences. Alignment of GtCel12A with Gloeophyllum trabeum Cel5B, Daedalea quercina GH12, Laetiporus sulphureus GH12, Neolentinus lepideus GH12, Postia placenta GH12, Trichoderma reesei Cel12A, Cel5A, and Cel7B. Identical regions are indicated by black background. Conserved and similar regions are indicated in dark and light gray, respectively. A arrows, helices, and stars indicate $\beta$-sheet regions, a-helix regions, and deduced catalytic residues (E122 and E207), respectively. Figure S2. Western blot analysis and sodium dodecyl sulfate-polyacrylamide gel electrophoresis (SDS-PAGE) of GtCel12A. (a) The purified enzyme was detected by western blot assay with a mouse anti-His tag. (b) Purified recombinant GtCel12A from Pichia pastoris was loaded on a 12\% (W/V) SDS-PAGE gel and stained with Coomassie blue. Lane S/M: molecular weight size marker, lane 1: purified recombinant GtCel12A, lane 2: purified recombinant GtCel5B.

\section{Abbreviations}

BSA: bovine serum albumin; CAZy: Carbohydrate-Active enZYmes database; CMC: carboxymethyl cellulose; DNS: dinitrosalicylic acid; GH: glycoside hydrolase; HPAC: hydrogen peroxide-acetic acid; HPLC: high-performance liquid chromatography; LB: Luria-Bertani; PCR: Polymerase chain reaction; PDA: potato dextrose agar; SDS-PAGE: sodium dodecyl sulfate polyacrylamide gel electrophoresis; TLC: thin-layer chromatography; YPD: yeast extract peptone dextrose; YPG: yeast extract peptone glycerol; 3D: three-dimensional.

\section{Acknowledgements}

This work was supported by the National Research Foundation of Korea (NRF) Grant funded by the Korea Government (MSIP) (No. 2018R1A2A2A05018238).

\section{Authors' contributions}

$\mathrm{CHO}, \mathrm{YS}$, and $\mathrm{H}-\mathrm{JB}$ designed and planned the research. $\mathrm{CHO}, \mathrm{CSP}$, and YGL performed the experiments. $\mathrm{CHO}$ wrote the manuscript with contributions of CSP. H-JB supervised the experiments and manuscript. All authors read and approved the final manuscript.

\section{Funding}

This work was supported by the National Research Foundation of Korea (NRF) Grant funded by the Korea Government (MSIP) (No. 2018R1A2A2A05018238).

\section{Availability of data and materials}

All data generated or analyzed during this study are included in this published article and Additional file 1.

\section{Consent for publication}

Informed consent was obtained from all individual participants in the study.

\section{Competing interests}

The authors declare that they have no competing interests.

\section{Author details}

${ }^{1}$ Department of Bioenergy Science and Technology, Chonnam National University, Gwangju 61186, Republic of Korea. ${ }^{2}$ Bio-Energy Research Center, Chonnam National University, Gwangju 61186, Republic of Korea.

Received: 27 February 2019 Accepted: 12 June 2019

Published online: 21 June 2019

\section{References}

1. Behera SS, Ray RC (2016) Solid state fermentation for production of microbial cellulases: recent advances and improvement strategies. Int J Biol Macromol 86:656-669

2. Horn SJ, Vaaje-Kolstad G, Westereng B, Eijsink VG (2012) Novel enzymes for the degradation of cellulose. Biotechnol Biofuels 5:45

3. Hasunuma T, Okazaki F, Okai N, Hara KY, Ishii J, Kondo A (2013) A review of enzymes and microbes for lignocellulosic biorefinery and the possibility of their application to consolidated bioprocessing technology. Bioresour Technol 135:513-522

4. Kuhad RC, Gupta R, Singh A (2011) Microbial cellulases and their industrial applications. Enzyme Res 2011:280696

5. Srivastava N, Rawat R, Singh Oberoi H, Ramteke PW (2015) A review on fuel ethanol production from lignocellulosic biomass. Int J Green Energy 12(9):949-960

6. Cherry JR, Fidantsef AL (2003) Directed evolution of industrial enzymes: an update. Curr Opin Biotechnol 14(4):438-443

7. Schuster A, Schmoll M (2010) Biology and biotechnology of Trichoderma. Appl Microbiol Biotechnol 87(3):787-799

8. Baldrian P, Valaskova V (2008) Degradation of cellulose by basidiomycetous fungi. FEMS Microbiol Rev 32(3):501-521

9. Floudas D, Binder M, Riley R, Barry K, Blanchette RA, Henrissat B, Martinez AT, Otillar R, Spatafora JW, Yadav JS, Aerts A, Benoit I, Boyd A, Carlson A, Copeland A, Coutinho PM, de Vries RP, Ferreira P, Findley K, Foster B, Gaskell J, Glotzer D, Gorecki P, Heitman J, Hesse C, Hori C, Igarashi K, Jurgens JA, Kallen N, Kersten P, Kohler A, Kues U, Kumar TK, Kuo A, LaButti K, Larrondo LF, Lindquist E, Ling A, Lombard V, Lucas S, Lundell T, Martin R, McLaughlin DJ, Morgenstern I, Morin E, Murat C, Nagy LG, Nolan M, Ohm RA, Patyshakuliyeva A, Rokas A, Ruiz-Duenas FJ, Sabat G, Salamov A, Samejima M, Schmutz J, Slot JC, St John F, Stenlid J, Sun H, Sun S, Syed K, Tsang A, Wiebenga A, Young D, Pisabarro A, Eastwood DC, Martin F, Cullen D, Grigoriev IV, Hibbett DS (2012) The Paleozoic origin of enzymatic lignin decomposition reconstructed from 31 fungal genomes. Science 336(6089):1715-1719

10. Cohen R, Suzuki MR, Hammel KE (2005) Processive endoglucanase active in crystalline cellulose hydrolysis by the brown rot basidiomycete Gloeophyllum trabeum. Appl Environ Microbiol 71(5):2412-2417

11. Kerem Z, Jensen KA, Hammel KE (1999) Biodegradative mechanism of the brown rot basidiomycete Gloeophyllum trabeum: evidence for an extracellular hydroquinone-driven fenton reaction. FEBS Lett 446(1):49-54

12. Suzuki MR, Hunt CG, Houtman CJ, Dalebroux ZD, Hammel KE (2006) Fungal hydroquinones contribute to brown rot of wood. Environ Microbiol 8(12):2214-2223

13. Takeda T, Takahashi M, Nakanishi-Masuno T, Nakano Y, Saitoh H, Hirabuchi A, Fujisawa S, Terauchi R (2010) Characterization of endo-1,3-1,4- $\beta$ glucanases in GH family 12 from Magnaporthe oryzae. Appl Microbiol Biotechonol 88:1113-1123

14. Linger JG, Adney WS, Darzins A (2010) Heterologous expression and extracellular secretion of cellulolytic enzymes by Zymomonas mobilis. Appl Environ Microbiol 76(19):6360-6369

15. Nakazawa H, Okada K, Kobayashi R, Kubota T, Onodera T, Ochiai N, Omata N, Ogasawara W, Okada H, Morikawa Y (2008) Characterization of the catalytic domains of Trichoderma reesei endoglucanase I, II, and III, expressed in Escherichia coli. Appl Microbiol Biotechnol 81(4):681-689 
16. Miotto LS, de Rezende CA, Bernardes A, Serpa VI, Tsang A, Polikarpov I (2014) The characterization of the endoglucanase Cel12A from Gloeophyllum trabeum reveals an enzyme highly active on beta-glucan. PLoS ONE 9(9):e108393

17. Segato F, Dias B, Berto GL, de Oliveira DM, De Souza FHM, Citadini AP, Murakami MT, Damasio ARL, Squina FM (1865) Polikarpov I (2017) Cloning, heterologous expression and biochemical characterization of a non-specific endoglucanase family 12 from Aspergillus terreus NIH2624. Biochim Biophys Acta Proteins Proteom 4:395-403

18. Xian L, Wang F, Yin X, Feng JX (2016) Identification and characterization of an acidic and acid-stable endoxyloglucanase from Penicillium oxalicum. Int J Biol Macromol 86:512-518

19. Tambor JH, Ren H, Ushinsky S, Zheng Y, Riemens A, St-Francois C, Tsang A, Powlowski J, Storms R (2012) Recombinant expression, activity screening and functional characterization identifies three novel endo-1,4-betaglucanases that efficiently hydrolyse cellulosic substrates. Appl Microbiol Biotechnol 93(1):203-214

20. Ahmad M, Hirz M, Pichler H, Schwab H (2014) Protein expression in Pichia pastoris: recent achievements and perspectives for heterologous protein production. Appl Microbiol Biotechnol 98(12):5301-5317

21. Cereghino JL, Cregg JM (2000) Heterologous protein expression in the methylotrophic yeast Pichia pastoris. FEMS Microbiol Rev 24(1):45-66

22. Cregg JM, Tolstorukov I, Kusari A, Sunga J, Madden K, Chappell T (2009) Expression in the yeast Pichia pastoris. Methods Enzymol 463:169-189

23. Wi SG, Cho EJ, Lee DS, Lee SJ, Lee YJ, Bae HJ (2015) Lignocellulose conversion for biofuel: a new pretreatment greatly improves downstream biocatalytic hydrolysis of various lignocellulosic materials. Biotechnol Biofuels 8:228

24. Miller GL (1959) Use of dinitrosalicylic acid reagent for determination of reducing sugar. Anal Chem 31:426-428

25. Kim HM, Lee YG, Patel DH, Lee KH, Lee DS, Bae HJ (2012) Characteristics of bifunctional acidic endoglucanase (Cel5B) from Gloeophyllum trabeum. J Ind Microbiol Biotechnol 39(7):1081-1089

26. Okada H, Tada K, Sekiya T, Yokoyama K, Takahashi A, Tohda H, Kumagai H, Morikawa Y (1998) Molecular characterization and heterologous expression of the gene encoding a low-molecular-mass endoglucanase from Trichoderma reesei QM9414. Appl Environ Microbiol 64(2):555-563

27. Master ER, Zheng Y, Storms R, Tsang A, Powlowski J (2008) A xyloglucanspecific family 12 glycosyl hydrolase from Aspergillus niger: recombinant expression, purification and characterization. Biochem J 411(1):161-170

28. Calzado F, Prates ET, Goncalves TA, Rubio MV, Zubieta MP, Squina FM, Skaf MS, Damasio AR (2016) Molecular basis of substrate recognition and specificity revealed in family 12 glycoside hydrolases. Biotechnol Bioeng 113(12):2577-2586
29. Imran M, Anwar Z, Irshad M, Asad MJ, Ashfaq H (2016) Cellulase production from species of fungi and bacteria from agricultural wastes and its utilization in industry: a review. Adv Enzyme Res 4:44-55

30. Vaishnav N, Singh A, Adsul M, Dixit P, Sandhu SK, Mathur A, Puri SK, Singhania RR (2018) Penicillium: the next emerging champion for cellulase production. Bioresour Technol Rep 2:131-140

31. Grishutin SG, Gusakov AV, Dzedzyulya El, Sinitsyn AP (2006) A lichenaselike family 12 endo-( $1 \rightarrow$ 4)-beta-glucanase from Aspergillus japonicus: study of the substrate specificity and mode of action on beta-glucans in comparison with other glycoside hydrolases. Carbohydr Res 341(2):218-229

32. Samanta S, Basu A, Halder UC, Sen SK (2012) Characterization of Trichoderma reesei endoglucanase II expressed heterologously in Pichia pastoris for better biofinishing and biostoning. J Microbiol 50(3):518-525

33. Naika GS, Tiku PK (2011) Influence of ethylenediaminetetraacetic acid (EDTA) on the structural stability of endoglucanase from Aspergillus aculeatus. J Agric Food Chem 59(13):7341-7345

34. Karlsson J, Siika-aho M, Tenkanen M, Tjerneld F (2002) Enzymatic properties of the low molecular mass endoglucanases Cel12A (EG III) and Cel45A (EG V) of Trichoderma reesei. J Biotechnol 99(1):63-78

35. Nakagame S, Chandra RP, Saddler JN (2010) The effect of isolated lignins, obtained from a range of pretreated lignocellulosic substrates, on enzymatic hydrolysis. Biotechnol Bioeng 105(5):871-879

36. Várnai A, Siika-aho M, Viikari L (2010) Restriction of the enzymatic hydrolysis of steam-pretreated spruce by lignin and hemicellulose. Enzyme Microb Technol 46(3-4):185-193

37. Karimi K, Taherzadeh MJ (2016) A critical review of analytical methods in pretreatment of lignocelluloses: composition, imaging, and crystallinity. Bioresour Technol 200:1008-1018

38. Narra M, Dixit G, Divecha J, Kumar K, Madamwar D, Shah AR (2014) Production, purification and characterization of a novel GH 12 family endoglucanase from Aspergillus terreus and its application in enzymatic degradation of delignified rice straw. Int Biodeterior Biodegrad 88:150-161

39. Jagtap SS, Dhiman SS, Kim T-S, Kim I-W, Lee J-K (2014) Characterization of a novel endo- $\beta$-1,4-glucanase from Armillaria gemina and its application in biomass hydrolysis. Appl Microbiol Biotechnol 98(2):661-669

\section{Publisher's Note}

Springer Nature remains neutral with regard to jurisdictional claims in published maps and institutional affiliations.

\section{Submit your manuscript to a SpringerOpen ${ }^{\circ}$ journal and benefit from:}

- Convenient online submission

- Rigorous peer review

- Open access: articles freely available online

- High visibility within the field

Retaining the copyright to your article

Submit your next manuscript at springeropen.com 